\title{
Mobile phone-induced honeybee worker piping
}

\author{
Daniel FAVRE ${ }^{1,2}$ \\ ${ }^{1}$ Scientific collaborator in the Laboratory of Cellular Biotechnology (LBTC), Swiss Federal Institute of Technology \\ (EPFL), Lausanne, Switzerland \\ ${ }^{2}$ Apiary School of the City of Lausanne, Chemin du Bornalet 2, CH-1066, Épalinges, Switzerland
}

Received 24 June 2009 - Revised 29 March 2010 - Accepted 8 April 2010

\begin{abstract}
The worldwide maintenance of the honeybee has major ecological, economic, and political implications. In the present study, electromagnetic waves originating from mobile phones were tested for potential effects on honeybee behavior. Mobile phone handsets were placed in the close vicinity of honeybees. The sound made by the bees was recorded and analyzed. The audiograms and spectrograms revealed that active mobile phone handsets have a dramatic impact on the behavior of the bees, namely by inducing the worker piping signal. In natural conditions, worker piping either announces the swarming process of the bee colony or is a signal of a disturbed bee colony.
\end{abstract}

worker bee / acoustic communication / mobile phone handset / worker piping / induction

\section{INTRODUCTION}

Honeybees are essential partners for the success of agriculture. The economical role of honeybees in worldwide pollination has been valued to be around 153 billion euros in the year 2005 (Gallai et al. 2009). Bee losses have been recorded for more than a century (Hart 1893; Aikin 1897; Beuhne 1910; Wilson and Menapace 1979). Scientists suspect many factors to be responsible for the killing of the bees, of which the varroa mite, pesticides, viruses, farming practices, monoculture, hygiene in the hive, and climatic factors are the most widely cited possibilities. Starting in 2003-2004, bee colonies worldwide suddenly began to show symptoms of the so-called colony collapse disorder (CCD). CCD initially affects the worker bees, which desert the hive. The queen bee is usually abandoned in the hive

Corresponding author: D. Favre, daniel_favre@yahoo.com

Manuscript editor: Yves Le Conte with the young brood and with an abundance of honey, so that the colony can survive for a very short time. However, without the worker bee population, the colony becomes unsustainable and dies out. Never before have honeybees disappeared globally and at such a high rate.

Current theories about the potential cause(s) of CCD essentially include increased losses due to the invasive varroa mite (Donzé et al. 1998). Pesticide poisoning (through exposure to pesticides applied for crop pest control), potential immune-suppressing stress on bees (caused by one or a combination of several factors such as apiary overcrowding, pollination of crops with low nutritional value, pollen or nectar dearth), drought, monocultural practices, migratory stress (brought about by the moving of the bees in long distances), and increased transmission of pathogens have also been usually cited as a cause of CCD (U.S.D.A. 2007). Other causes might include genetically modified crops (Malone and Pham-Delegue 2001) and exceptionally cold winters. 
Recent efforts have been made to study another potential cause responsible for bee losses: man-made electromagnetic fields. The results obtained to date have been highly controversial. In princeps studies performed by using digitally enhanced cordless telephones located in the bottom of beehives, it has been shown that exposed honeybees were perturbed in their returning behavior to the hive after foraging (Harst et al. 2006; Diagnose-Funk 2007; Stever et al. 2007).

Honeybees possess magnetite crystals in their fat body cells and they present magnetic remanence (Gould et al. 1978; Keim et al. 2002). These magnetite structures are active parts of the magnetoreception system in honeybees (Hsu and Li 1994; Hsu et al. 2007). Honeybees can be trained to respond to very small changes in the constant local geomagnetic field intensity (Walker and Bitterman 1989a). They can also communicate through chemical and acoustical means (Winston 1991; Tautz 2008). Therefore, the analysis of the sound features of bee colonies was a method of choice in the present study, since it can be correlated with the activity of the bees (Esch 1967; Michelsen et al. 1986; Donahoe et al. 2003; Pierce et al. 2007; Ferrari et al. 2008).

To my knowledge, no systematic studies have been conducted on potential effects of electromagnetic radiation from mobile phones on honeybee behavior. Here, I present results from corresponding original experiments I have carried out with honeybee populations exposed to active mobile phone radiation. The goal of these experiments was to identify potential effects of mobile phone communications on honeybee behavior and to establish simple methodology to enable other beekeepers to reproduce the experiments.

\section{MATERIALS AND METHODS}

\subsection{Sound recording and analysis}

An acoustical method based on sound analysis for classification was employed to identify the changes triggered by mobile phone handsets on the behavior of the honeybee Apis mellifera carnica. The sounds produced by the bees in their normal activities were recorded as negative control (with or without inactive mobile phones in the hive); activity of the bees was also recorded with active mobile phones in the hive (see below). Five healthy hives (either Dadant-Blatt or Swiss Bürki types) were monitored for sound during several recordings performed between February and June 2009. During the previous autumns and winters, the bees had been treated against the varroa mite Varroa destructor with formic acid and oxalic acid, as recommended elsewhere (Charrière et al. 2004). Beehives were located either in the beekeeping and apiary school of the city of Lausanne (altitude, $749 \mathrm{~m}$ ) or in a second site used by beekeepers north of the city of Morges (altitude, $510 \mathrm{~m}$; both locations in Switzerland). The recording device consisted of a bidirectional compact microphone (Olympus ME-31) with frequency response from 70 to $14,000 \mathrm{~Hz}$ connected to a vocal recorder (Olympus LS10). The use of omnidirectional microphones such as the ECM 3005 (Monacor) or the electret condenser 333013 (Radio Shack) is also possible, as described elsewhere (Ferrari et al. 2008; Rangel and Seeley 2008). The recorded signal was digitized as a Waveform audio file format sound file with $160 \mathrm{kbps}$. The computer program Adobe Audition 1.5 was employed for the manual analysis of the sound files and for the generation of the audiograms (also called sonograms) and spectrograms (oscillograms), as described elsewhere (Ferrari et al. 2008).

In this pilot study, more than 80 different sound recordings were performed in five different hives throughout the assay period starting early February and ending June 2009. In the geographic area where the experiments took place, the bees usually begin to forage to collect nectar and pollen in early March, depending on the weather conditions.

Sounds made by honeybees were recorded in the two conventional models of hives (Swiss Bürki and Dadant-Blatt) that are found in Switzerland.

\subsection{Mobile phone experimental arrangement}

Two mobile phone handsets were randomly chosen from a selection of four different apparatus having specific energy adsorption rate (SAR) values of either $0.271,0.62,0.81$, or $0.98 \mathrm{~W} / \mathrm{kg}$ (tissue) and 
$900 \mathrm{MHz}$ GSM roaming (Global System for Mobile communications, originally from Groupe Spécial Mobile). The sum of the two random SAR values was always below the $2-\mathrm{W} / \mathrm{kg}$ maximum upper limits recommended in the guidelines of the International Commission on Non-Ionizing Radiation Protection (I.C.N.I.R.P 1998). Four different subscriber identity module cards unrelated to the experimenter were randomly used.

For negative controls, the two apparatus were not present in the hive during the recording of the natural background sounds made by the bees. For undisturbed control experiments ("sham" experiments), the two mobile phone handsets were either shut down or kept in the standby mode. The basic setup of the experiments is schematically shown in Figure 1.

In order to establish whether inactive mobile phone handsets perturbed the behavior of the bees, two mobile phone handsets were placed in the hive in close vicinity of the honeybees. In a first series of experiments (negative control; $n=8$ ), two inactive ("off" mode) mobile phone handsets were placed in the hive for up to $24 \mathrm{~h}$. In a second series of experiments (sham experiments, "standby" mode; $n=10$ ), the two mobile phone handsets were kept in the hive in the standby mode, for prolonged periods of time (4 to $24 \mathrm{~h}$ ). As positive control experiments, the two mobile phone handsets were employed in an active communication mode. The first mobile phone was placed in the hive

Figure 1. Apparatus positioning in the different hives. a Schematic drawing. Sound recorder 1 was connected to a microphone 2 , the latter was placed in the close vicinity of the bees in the hive. The first (emitting) mobile phone 3 was connected with hands-free kit, the latter having its small microphone maintained on the loudspeaker of a radio apparatus 4 . A second (receiving) mobile phone 5, also having a hands-free kit, was also kept inside the hive. The use of the radio apparatus is intended to allow a permanent communication between the two mobile phone handsets, in order to avoid unwanted disconnection after a while. b Image of a Dadant-Blatt model of beehive. The microphone is placed through the upper nourishing hole. c Image of a Swiss Bürki model of beehive. The microphone was placed behind a board having a grid instead of a glass plate. During the experiments, the door of the Bürki hive was closed and the Dadant-Blatt hive was covered with the roof. A similar positioning can be easily performed with other types of beehives. and was supplemented with a hands-free kit, the mini microphone of which was held in front of a radio apparatus maintained outside the hive $(\approx 60 \mathrm{~cm}$ away, so that it does not interfere with the recording performed by the microphone near the bees) and constantly playing the France info program (output of the small radio loudspeaker, $-18 \pm 2 \mathrm{~dB}$ at $1 \mathrm{~cm}$ ). This enables a permanent signal to be sent from this first to a second telephone, otherwise without this signal the communication is automatically interrupted after a period of time. To generate a mobile phone communication near the bees, the first mobile phone was
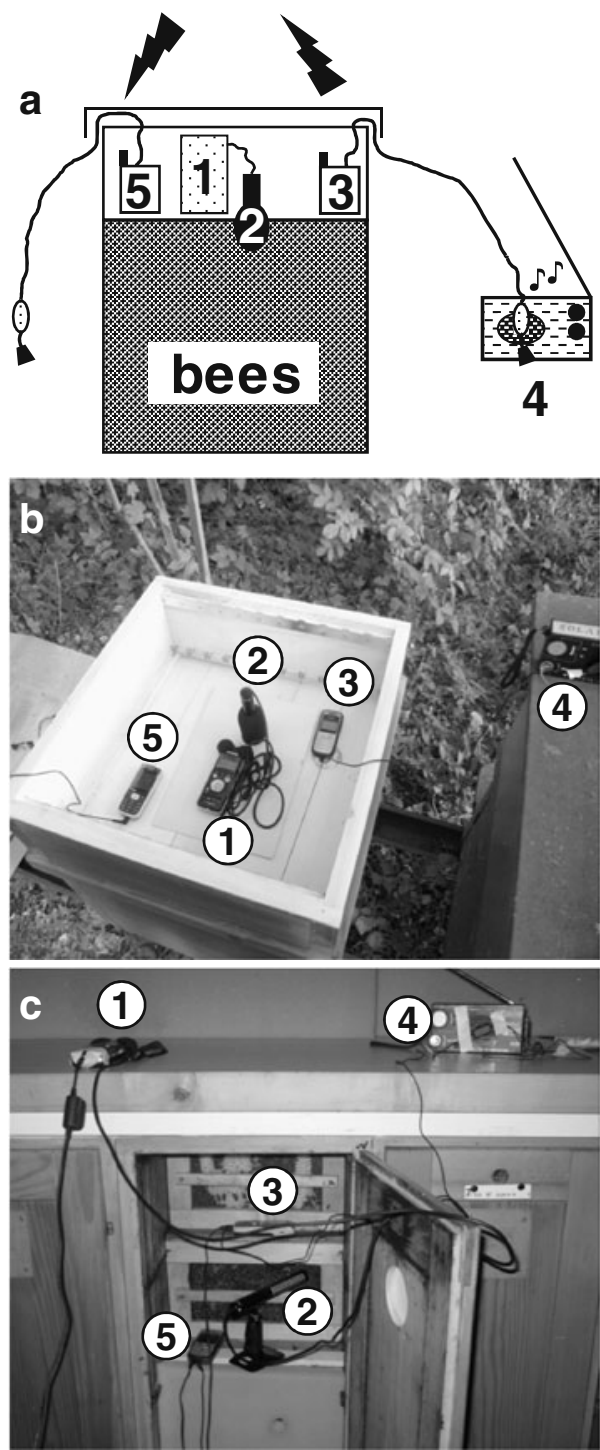
triggered to call a second mobile phone that was also placed in the hive. The communication was established after a ringing signal lasting from 5 to $10 \mathrm{~s}$. This second apparatus was also supplemented with a handsfree kit. The sum of the SAR values of the two mobile phones was always below the recommended limit of $2 \mathrm{~W} / \mathrm{kg}$, as mentioned above. Several independent experiments $(n=12)$ with the presence of actively communicating mobile phone handsets in the hive were performed. The established active mobile phone communication could be controlled at any time in two different ways: by direct hearing of the communication using the hands-free kit from the second mobile phone, or by controlling the functional state of the communication by calling - from a third independent telephone - one of the two active mobile phone handsets involved in the experiment.

For each experiment, local weather parameters (temperature, wind, precipitation, atmospheric pressure, and duration of sunshine) were obtained from the Office Fédéral de Météorologie et de Climatologie (MétéoSuisse).

\section{RESULTS}

\subsection{Background control experiments}

The analysis of the sound files revealed similar characteristics and events that were not dependent on the model of the beehive (Figure 2). Beehives undisturbed by a mobile phone apparatus revealed the same sound characteristics as previously reported for other honeybee colonies (see "Discussion"). The fundamental frequency of $A$. mellifera carnica was in the range of 450 to $500 \mathrm{~Hz}$. Slightly less activity of the bees was recorded during the

Figure 2. Spectrograms and audiograms of hive sounds. a, c Swiss Bürki model. b, d Dadant-Blatt model. a, b without any mobile phones in the hive. $\mathbf{c}$, d with two mobile phones kept in standby mode in the hives. Intensity values of audiograms might vary between beehives, depending on the microphone positioning and the number of bees in the undisturbed hive. Spectrograms are reported in hertz $(\mathrm{Hz})$; audiograms are normalized (n.a. -1 to +1 ). Time $(t)$ is indicated in minutes. night than during the day. More sound intensities were recorded during spring and early summer than during winter, thus probably reflecting the number of the active bees present in the hives.
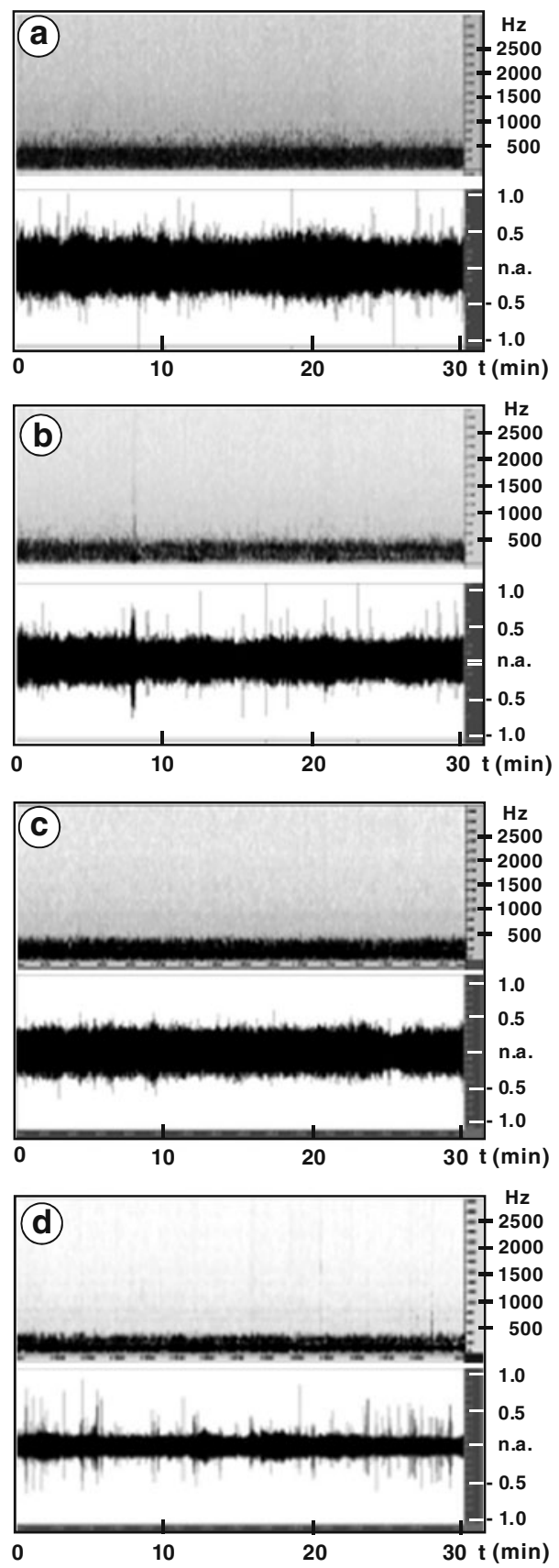


\subsection{Mobile phone handsets in standby mode in the hive}

The analysis of the various sound files revealed that the bees were not disturbed by these inactive or standby mobile phone handsets, since no dramatic changes in the fundamental intensity and frequency patterns of the sounds produced in the hive were recorded (Figure 2c, d), as compared to the background experiments performed without any mobile phone handsets (Figure 2a, b).

\subsection{Mobile phone handsets activated in the hive}

A result from a typical sound recording experiment is shown in Figure 3a. Mobile phone handsets in the hive were initially kept for a while (around $25 \mathrm{~min}$ ) in standby mode and then put in an active communication mode. Sound analysis in the beehive revealed that the bees initially remained calm after the onset of the communication mode, but started to produce sounds that were higher in both frequency and amplitude after about $30 \mathrm{~min}$ of communication of the mobile phone handsets. After about 15 additional minutes, the mobile phone handset communication was interrupted. The bees returned to a quiet state after 2 to $3 \mathrm{~min}$, since the frequency and intensity in the hive had returned to the basal values recorded in the beginning of the experiment. Negative control runs showed that the radio itself did not induce any changes in bee behavior with mobile handsets deactivated.

In order to assess how much time the bees would need to return to a basal sound status after mobile phone communication, experiments were performed by placing in the hive actively communicating mobile phone handsets for prolonged periods of time ranging up to $20 \mathrm{~h}$. Sound analysis revealed that the bees' sound values increased in both the intensity and amplitude ranges throughout the experimental period, as compared to background values prior to onset of the mobile phone communication. In each of the independent experiments, both the sound intensity and the frequency increased
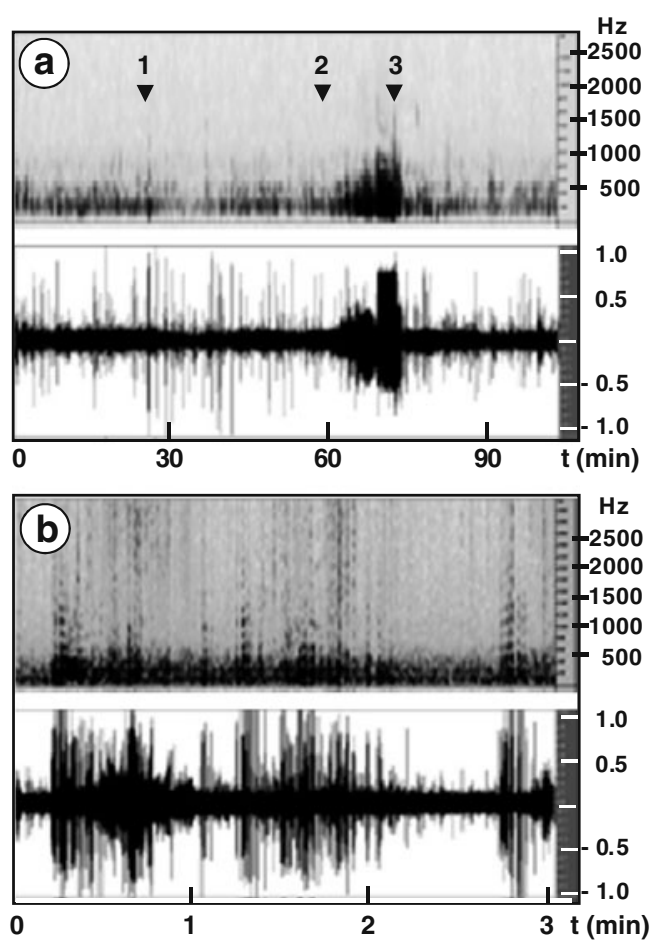

Figure 3. Induction of honeybee worker piping by mobile phone handsets. a standby mobile phone handsets in the hive were activated $25 \mathrm{~min}$. after the onset of the experiment (1). The beginning of increased noise and frequency in the hive was observed ca. 35 min later (2) and is indicated by a longer arrow. The cessation of the mobile phone communication is indicated (3). b Recording of bee noise in a hive submitted to prolonged $(20 \mathrm{~h})$ active mobile phone handsets. Spectrograms are reported in hertz $(H z)$; audiograms are normalized (n.a. -1 to +1$)$. Time $(t)$ is indicated in minutes.

about 25 to $40 \mathrm{~min}$ after the onset of the mobile phone communication. Twelve hours after the cessation of the mobile phone communication in the hive, the bees were still producing more sound in both intensity and frequency as compared to the initial background mode, suggesting that the behavior of the bees remained perturbed for up to $12 \mathrm{~h}$ after the end of a prolonged mobile phone communication. Analysis of a shorter period of time lasting $3 \mathrm{~min}$ is presented (Figure $3 \mathrm{~b}$ ). 
When the sound produced by honeybees in hives containing active mobile phone handsets was analyzed in more detail, it was determined that the bees were producing the so-called "worker piping" (Figure 4a). Spectrograms obtained in the present study revealed various modes of worker piping. First, bimodal pipes
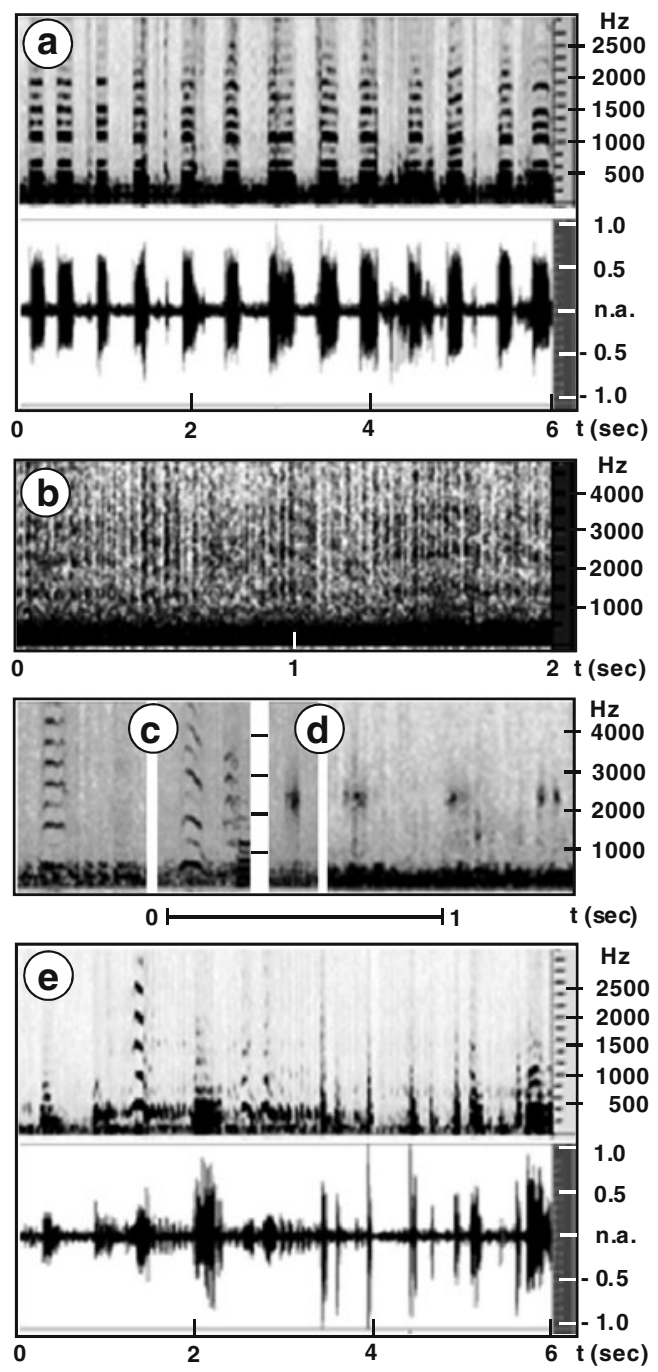

Figure 4. Mobile phone-induced honeybee worker piping. Various modes of worker piping $(\mathbf{a}-\mathbf{e})$ were recorded in the presence of actively communicating mobile phone handsets in the hive. Spectrograms are reported in hertz $(\mathrm{Hz})$; audiograms are normalized (n.a. -1 to +1$)$. Time $(t)$ is indicated in seconds. having a fundamental frequency of around 150$250 \mathrm{~Hz}$ and a duration of about $200 \pm 51 \mathrm{~ms}(n=60$ pipes) and $430 \pm 103 \mathrm{~ms}$ ( $n=30$ pipes) were recorded throughout the experiment involving mobile phone handsets communication in the hive. The harmonic nature of each pipe, as compared to results presented elsewhere (Seeley and Tautz 2001), was also evident. Another shorter type of worker piping, having a fundamental frequency of around $400-500 \mathrm{~Hz}$ and a duration of about $9 \pm 2 \mathrm{~ms}$ ( $n=50$ pipes), was also recorded as a prolonged succession of pulses lasting together up to $2 \mathrm{~s}$ (Figure $4 \mathrm{~b}$ ). This short piping signal was also presenting harmonic features ranging up to several thousand hertz. Two other types of signals were also recorded; however, less often than the two signals described above, a strong harmonic piping signal with a basal frequency of $500 \pm 50 \mathrm{~Hz}$ and lasting $75 \pm 15 \mathrm{~ms}$ (Figure 4c; $n=10$ ) and a signal with a basal frequency of around $2,250 \pm 250 \mathrm{~Hz}$ and lasting $225 \pm 50 \mathrm{~ms} \quad(n=10$; Figure $4 \mathrm{~d})$. Analysis of some recordings presented a mixture of the signals mentioned above (Figure 4e). All these different signals were recorded solely in beehives that were subjected to the influence of actively communicating mobile phone handsets, irrespective of both the location and the season when the experiments were performed. Moreover, the observations of worker piping were also independent of the weather conditions prevailing during the experiments.

\section{DISCUSSION}

The results of the present pilot study clearly show that the presence of actively communicating mobile phone handsets in the close vicinity of honeybees had a dramatic effect, namely the induction of worker piping which was regularly observed about 25 to $40 \mathrm{~min}$ after the onset of the mobile phone communication. This observation means that: (1) honeybees are sensitive to pulsed electromagnetic fields generated by the mobile telephones and (2) under these circumstances, observable changes in the behavior of the bees are not artificial, but can be proven to occur reproducibly. Although mobile 
phones are not present in the close vicinity of honeybees in real life, this study provides elements for the establishment of further experiments involving such apparatus placed at increasing distances from the bees. Potential consequences of these observations are discussed below in more detail.

\subsection{Rationale of the experimental design}

The experimental design employed was set up in order to enable beekeepers and researchers in the field to easily reproduce the experiments with the use of conventional materials and userfriendly computer programs. Honeybees are usually not living in the close vicinity of electromagnetic fields induced by mobile phone handsets in the hive. However, the conditions employed in the present experiments have biological significance, since the sum of the SAR values from the two mobile phone handsets were always below the 2$\mathrm{W} / \mathrm{kg}$ maximal value recommended for this frequency (I.C.N.I.R.P 1998). It seems likely that a similar effect on bees can occur with relatively low-dose exposure over a prolonged period of time. In this context, it should be emphasized that radio frequency electromagnetic fields (RF-EMF) have increased by an order of magnitude over the last 20 years in Switzerland; a mean weekly exposure of $0.13 \mathrm{~mW} / \mathrm{m}^{2}$ (83.8\% of all emitting RF-EMF) has been reported (Frei et al. 2009). Since both randomly visited outdoor locations and the proximity to mobile phone base stations showed a mean RF-EMF exposure of $0.21 \mathrm{~mW} /$ $\mathrm{m}^{2}$, experiments employing two mobile phone handsets in the hive were finally chosen for practical reasons. The experiments described in this article might therefore be applicable everywhere, since nearly all countries in the world today are readily covered with GSM networks (GSM roaming, coverage maps).

\subsection{Mobile phone handsets and induced honeybee worker piping}

It is known that honeybees possess magnetite crystals in their fat body cells and that they present magnetic remanence (Gould et al. 1978; Keim et al. 2002). These magnetite structures are active parts of the magnetoreception system in honeybees (Hsu and Li 1994; Hsu et al. 2007). Importantly, it has been shown that honeybees can be trained to respond to very small changes in the constant local geomagnetic field intensity (Walker and Bitterman 1989a). In that study, magnetic anomalies as low as $26 \mathrm{nT}$ (nanoTesla) were responsible for changes in the foraging behavior. Moreover, attached magnets impair magnetic field discrimination by honeybees (Walker and Bitterman 1989b). Therefore, it remains to be established which minimal level in variations of the local pulsed electromagnetic fields induced by mobile phone handsets and base stations might trigger changes in the bees' behavior, such as the induction of honeybee worker piping shown here. It is known for several decades that worker piping is associated with disturbance of the hive by, for example, intruders or jarring (Wenner 1964). The latter author recorded sounds that were called "croaking" and "bipping." This may present one explanation for the present observations assuming that mobile phone handsets triggered disturbances in the hive in a similar way (see Figure 4).

The experiments presented in this pilot study should be reproduced in hives totally protected or not with additional copper or aluminum Faraday cages. Additional clues for the ferromagnetic transduction hypothesis (Kirschvink and Gould 1981) and a plausible mechanism for the sensitivity of honeybees to localized electromagnetic anomalies might therefore be obtained. Such behavioral changes cannot only be analyzed at the behavioral level with sound analysis, but also at the molecular level by studying the gene expression profiles using microarrays, as it was done for the infestation of honeybees with the varroa mite (Navajas et al. 2008).

Although worker piping can be associated with foraging in undisturbed queenright colonies of honeybees (Pratt et al. 1996), it is usually a signal that is produced shortly before takeoff of a swarm (Seeley and Tautz 2001; Rangel and Seeley 2008). Worker piping in a bee colony is not frequent, and when it occurs in a colony, that is not in a swarming process, no 
more than two bees are simultaneously active (Pratt et al. 1996). The induction of honeybee worker piping by the electromagnetic fields of mobile phones might have dramatic consequences in terms of colony losses due to unexpected swarming. The present study suggests that active mobile phone handsets in beehives noticeably induce the rate of worker piping. However, no evidence for piping of the laying queen (see Schneider and Lewis 2004) was observed.

In the present study, no swarming process was initiated after $20 \mathrm{~h}$ of exposure to mobile phone handsets, even though the piping signal was observed. It should therefore be hypothesized that although the piping signal is serving as a primer for swarm exodus other modalities and/or signals (e.g., the shaking and buzz-run signals or chemical components) may be required in the complex swarming process (Rangel and Seeley 2008). The "buzz-run" or "Schwirrlauf" rate is perhaps the required crucial signal that appears $15 \mathrm{~min}$ before the massive exodus of honeybees during the swarm departure process (Seeley and Tautz 2001; Rangel and Seeley 2008). Moreover, it might be possible that a more prolonged exposure $(>20 \mathrm{~h})$ of the honeybees to the actively communicating mobile phone handsets is required for the complete induction of the swarming process. Recently, a study suggested that cell phones and cellphone towers near beehives interfere with honeybee navigation: in one experiment, it was found that when a mobile phone was kept near a beehive it resulted in collapse of the colony in 5 to 10 days, with the worker bees failing to return home, leaving the hives with just queens, eggs and hive-bound immature bees (Sahib Pattazhy 2009). To minimize harm to the bees, it was decided to limit their continuous exposure to mobile phone communications to a maximum of $20 \mathrm{~h}$ in the present study.

Further confirmation of the current results and their implications regarding a direct correlation between erratic honeybee behavior and mobile phone-generated electromagnetic fields would substantiate one more explanation for the "disappearance" of bee colonies around the world. This phenomenon accounts for $43 \%$ of all bee losses, apart from overwintering (39\%), mite disease,
$(15 \%)$ and pesticides (3\%) as recently described in a national survey performed in the United States (Bee Alert Technology 2007). Experiments should be undertaken to establish the correlation between the time necessary for the onset of worker piping and the intensity of the electromagnetic fields present in the vicinity of the beehive. For future experiments, in complement to the present original study and in order to reach more "natural" conditions, mobile phone apparatuses should be placed at various increasing distances away from the hives. Video recordings showing the modifications in the bees' behavior in the hive should also be performed.

\section{ACKNOWLEDGEMENTS}

This work was performed under the full responsibility of the main author (D.F.). I thank Prof. Jürgen Tautz for his scientific expertise, Prof. Harald Berresheim and Dr. David Hacker for the critical reading of the manuscript, Michel Roth for providing the opportunity to perform experiments in the apiary school of Lausanne, Dr. Jacques-Henri Penseyres and Pierre-André Bonzon for their interest in future experimental projects, the late Philippe Hug (to whom this scientific article is dedicated) and Peter Loepfe for helpful comments, and the beekeepers in the apiary clubs of Lausanne and Morges for their collaboration and scientific interest.

\section{Son émis par les ouvrières en réaction à la proximité d'un téléphone portable}

\section{Ouvrière / communication accoustique / téléphone portable / stimulus}

Mobiltelefon induzierte Piepstöne von Arbeiterinnen der Honigbiene. In den letzten Jahren häufen sich Berichte über einen weltweiten Schwund an Honigbienen in Folge einer Völkerverlustkrankheit (colony loss disease, CCD), bei der Völker massiv und plötzlich eingehen, ohne dass es vorhergehende Anzeichen einer Krankheit oder Parasitenbefall gibt. CCD hat schwerwiegende Auswirkungen für den Anbau vieler Früchte und Gemüse, die auf Bestäubung durch Insekten angewiesen sind Milbenbefall, Pestizide, eine reduzierte Immunität, bakterielle und virale Infektionen, genetisch modifizierte Feldfrüchte und Anbaupraktiken stehen im Verdacht, eine Rolle 
beim Schwund der Bienenvölker zu spielen. Berichten in wissenschaftlichen und allgemeinen Medien zufolge besteht auch die Möglichkeit, dass Mobiltelefone hierzu beitragen können, da Bienen Schwierigkeiten bei der Heimfindung hatten, wenn Basisstanionen für schnurlose Telefone unter den Völkern installiert waren. Mikrowellen könnten demzufolge einen Teil der Verantwortung für das CCD-Syndrom tragen. In dieser Arbeit untersuchte ich die potentiellen Effekte von konventionellen Mobiltelefonen produzierten elektromagnetischen Feldern auf Honigbienen. Hierzu wurden zwei Geräte im aktiven Modus und mit einer Summe an spezifischen Energieabsorptionsraten unterhalb der offiziellen internationalen Maximalwerte (2 Watt pro Kilo Gewebe) in der Nähe von Bienen aufgestellt und die von Bienen produzierten Piepstöne aufgezeichnet und analysiert. Dies zeigte, dass sich Bienen durch die aktiv kommunizierenden Mobiltelefone im Volk gestört fühlten und zum Senden von Piepstönen angeregt wurden. Unter natürlichen Bedingungen sind solche Piepstöne ein Signal für die Schwarmvorbereitung oder eine Reaktion auf Störungen im Volk. Das Senden von Piepstönen setzte nicht sofort nach Einschalten der Mobiltelefone ein, sondern erst nach 25 bis 40 Minuten. Diese Beobachtungen weisen darauf hin, dass die Bienen für pulsierende elektromagnetische Felder empfänglich sind und sensibel auf Verhaltensänderungen reagieren. Ein Schwund an Bienenvölkern wird v.a. in Erdteilen beobachtet (Nordamerika, Europa, Australien, Südbrasilien, Taiwan und Japan), in denen Mobiltelefone weit verbreitet sind. Es stellt sich daher die Frage, ob der Zusammenhang von CCD und einer intensiven Nutzung von Mobiltelefonen noch als reine Spekulation angesehen werden kann.

\section{Arbeiterinnen / akustische Kommunikation / Mobiltelefon / Arbeiterinnenpiepstöne}

Open Access This article is distributed under the terms of the Creative Commons Attribution Noncommercial License which permits any noncommercial use, distribution, and reproduction in any medium, provided the original author(s) and source are credited.

\section{REFERENCES}

Aikin, R.C. (1897) Bees evaporated: a new malady. Glngs. Bee Cult. 25, 479-480
Bee Alert Technology Inc. (2007) National honey bee loss survey - updated survey results, June 1, 2007: correlation of common pathogens with CCD. http://beealert. blackfoot.net/ beealert/UpdatedSurveyResults June19_2007.pdf. Accessed 15 Sept 2009

Beuhne, R. (1910) Bee mortality. J. Dept. Agric. Vic. 8, 149-151

Charrière, J.-D., Imdorf, A., Kuhn, R. (2004) Tolérance pour les abeilles de différents traitements hivernaux contre Varroa. http://www.alp.admin.ch/themen/ 00502/00515/00519/index.html?lang=fr. Accessed 15 Sept 2009

Diagnose-Funk, (2007) The big bee death. http:/www.heseproject.org/hese-uk/en/papers/bigbeedeath_0407.pdf. Accessed 15 Sept 2009

Donahoe, K., Lewis, L.A., Schneider, S.S. (2003) The role of the vibration signal in the house-hunting process of honey bee (Apis mellifera) swarms. Behav. Ecol. Sociobiol. 54, 593-600

Donzé, G., Fluri, P., Imdorf, A. (1998) A look under the cap: the reproductive behaviour of Varroa in the capped brood of the honey bee. Am. Bee J. 138, 528-533

Esch, H. (1967) Sounds produced by swarming honey bees. J. Comp. Physiol. A. 56, 408-411

Ferrari, S., Silva, M., Guarino, M., Berckmans, D. (2008) Monitoring of swarming sounds in bee hives for early detection of the swarming period. Comput. Electron. Agric. 62, 72-77

Frei, P., Mohler, E., Neubauer, G., Theis, G., Bürgi, A., Fröhlich, J., Braun-Fahrländer, C., Bolte, J., Egger, M., Röösli, M. (2009) Temporal and spatial variability of personal exposure to radio frequency electromagnetic fields. Environ. Res. 109, 779-785

Gallai, N., Salles, J.M., Settele, J., Vaissière, B.E. (2009) Economic valuation of the vulnerability of world agriculture confronted with pollinator decline. Ecol. Econ. 68, 810-821

Gould, J.L., Kirschvink, J.L., Deffeyes, K.S. (1978) Bees have magnetic remanence. Science 201, 1026-1028

Harst, W., Kuhn, J., Stever, H. (2006) Can electromagnetic exposure cause a change in behaviour? Studying possible non-thermal influences on honey bees - an approach within the framework of educational informatics. http://agbi.uni-landau.de/material_download/ IAAS_2006.pdf. Accessed 15 Sept 2009

Hart, F.M. (1893) The "nameless bee disease" California. Am. Bee 31, 468

Hsu, C.Y., Li, C.W. (1994) Magnetoreception in honeybees. Science 265, 95-97

Hsu, C.Y., Ko, F.Y., Li, C.W., Fann, K., Lue, J.T. (2007) Magnetoreception system in honeybees (Apis mellifera). PLOS. ONE 2, e395

I.C.N.I.R.P (1998) Guidelines for limiting exposure to time-varying electric, magnetic, and electromagnetic fields (up to $300 \mathrm{GHz}$ ), International Commission on Non-Ionizing Radiation Protection. Health. Phys. 74, 494-522 
Keim, C.N., Cruz-Landim, C., Carneiro, F.G., Farina, M. (2002) Ferritin in iron containing granules from the fat body of the honeybees Apis mellifera and Scaptotrigona postica. Micron. 33, 53-59

Kirschvink, A.K., Gould, J.L. (1981) Biogenic magnetite as a basis for magnetic field detection in animals. Biosystems 13, 181-201

Malone, L.A., Pham-Delegue, M.H. (2001) Effects of transgene products on honey bees (Apis mellifera) and bumblebees (Bombus sp.). Apidologie 32, 287-304

MétéoSuisse, MeteoSuisse - Office fédéral suisse de météorologie et de climatologie, Département fédéral suisse de l'intérieur. http://www.meteosuisse.admin. $\mathrm{ch} / \mathrm{web} / \mathrm{fr} / \mathrm{meteo} \cdot \mathrm{html}$

Michelsen, A., Kirchner, W.H., Lindauer, M. (1986) Sound and vibrational signals in the dance language of the honeybee, Apis mellifera. Behav. Ecol. Sociobiol. 18, 207-212

Navajas, M., Migeon, A., Alaux, C., Martin-Magniette, M., Robinson, G., Evans, J., Cros-Arteil, S., Crauser, D., Le Conte, Y. (2008) Differential gene expression of the honey bee Apis mellifera associated with Varroa destructor infection. BMC Genomics 9, 301.

Pierce, A.L., Lewis, L.A., Schneider, S.S. (2007) The use of the vibration signal and worker piping to influence queen behavior during swarming in honey bees, Apis mellifera. Ethology 113, 267-275

Pratt, S.C., Kühnholz, S., Seeley, T.D., Weidenmüller, A. (1996) Worker piping associated with foraging in undisturbed queenright colonies of honey bees. Apidologie 27, 13-20

Rangel, J., Seeley, T.D. (2008) The signals initiating the mass exodus of a honeybee swarm from its nest. Anim. Behav. 76, 1943-1952

Sahib Pattazhy, S. (2009) Mobile phone towers a threat to honey bees: Study. The Times of India, 31 August
2009. http://timesofindia.indiatimes.com/NEWS/ Science/Mobile-phone-towers-a-threat-to-honeybees-Study/articleshow/4955867.cms. Accessed 15 Sept 2009

Schneider, S.S., Lewis, L.A. (2004) The vibration signal, modulatory communication and the organization of labor in honey bees, Apis mellifera. Apidologie 35, 117-131

Seeley, T.D., Tautz, J. (2001) Worker piping in honey bee swarms and its role in preparing for liftoff. $\mathrm{J}$. Comp. Physiol. A. 187, 667-676

Stever H, Harst W, Kimmel S, Kuhn J, Otten C, Wunder B (2007) Change in behaviour of the honeybee Apis mellifera during electromagnetic exposure-followup study 2006 (Unpublished research report). http:// agbi.uni-landau.de/material_download/elmagexp_ bienen_06.pdf. Accessed 15 Sept 2009

Tautz, J. (2008) The buzz about bees: biology of a superorganism. Springer Verlag, Berlin

U.S.D.A., CCD Steering Committee (2007) Colony collapse disorder action plan. In: Service U.S.D.A.-A.R. (Ed.), Washington DC, pp 1-27. http:/www.ars.usda.gov/is/ br/ccd/ccd_actionplan.pdf. Accessed 15 Sept 2009

Walker, M.M., Bitterman, M.E. (1989a) Honeybees can be trained to respond to very small changes in geomagnetic-field intensity. J. Exp. Biol. 145, 489-494

Walker, M.M., Bitterman, M.E. (1989b) Attached magnets impair magnetic-field discrimination by honeybees. J. Exp. Biol. 141, 447-451

Wenner, A.M. (1964) Sound communication in honeybees. Sci. Am. 210, 116-124

Wilson, W.T., Menapace, D.M. (1979) Disappearing disease of honey bees-survey of the United States. Am. Bee. J. 119, 184-186

Winston, M.L. (1991) The biology of the honey bee. Harvard University Press, Cambridge 